\title{
Transatlantica
}

Revue d'études américaines. American Studies Journal

$2 \mid 2014$

Aesthetics of Theory in the Modern Era and Beyond / Photographie documentaire

\section{Justine S. Murison, The Politics of Anxiety in Nineteenth-Century American Literature}

\section{Christophe Chambost}

\section{(2) OpenEdition}

\section{Journals}

Electronic version

URL: https://journals.openedition.org/transatlantica/7094

DOI: $10.4000 /$ transatlantica.7094

ISSN: $1765-2766$

\section{Publisher}

Association française d'Etudes Américaines (AFEA)

Electronic reference

Christophe Chambost, "Justine S. Murison, The Politics of Anxiety in Nineteenth-Century American Literature", Transatlantica [Online], 2 | 2014, Online since 10 March 2015, connection on 04 February 2023. URL: http://journals.openedition.org/transatlantica/7094 ; DOl: https://doi.org/10.4000/ transatlantica.7094

This text was automatically generated on 4 February 2023.

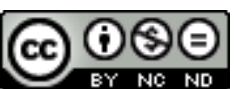

Creative Commons - Attribution-NonCommercial-NoDerivatives 4.0 International - CC BY-NC-ND 4.0 https://creativecommons.org/licenses/by-nc-nd/4.0/ 


\title{
Justine S. Murison, The Politics of Anxiety in Nineteenth-Century American Literature
}

\author{
Christophe Chambost
}

\section{REFERENCES}

MURISON, Justine S., The Politics of Anxiety in Nineteenth-Century American Literature, New York, Cambridge University Press, 2011, 218 pages, ISBN 978-1-107-69414-9, \$30/€23

1 Throughout her analysis Justine S. Murison focuses on the literary representations of some of the most characteristic conditions that affected the nervous system of nineteenth century America, those conditions having repercussions on the American society, whether it be socially or politically speaking.

2 The author first gives a theoretical introduction in which she announces the key notions that are to be tackled in the five chapters of the book, each chapter dealing with scientific themes related to specific authors and scholars. The epilogue, though rather short, enables the author to gain some perspective on the theme of anxiety and connect $19^{\text {th }}$ century somaticism to Freud and psychoanalysis. It is indeed made clear from the start that the author does not intend to give a psychoanalytical interpretation of anxiety. Instead, she develops a physiological approach of the role of the nervous system in American literature, and she shows what kind of repercussions it may have had on American society.

In chapter one, Murison thus puts forward the condition of hypochondria as well as the notion of sympathy while she examines Robert Montgomery Bird's Sheppard Lee. Chapter two focuses on Edgar Allan Poe's use of satire in tales where the physiology of the "reflex arc" (a discovery about the nervous system in the 1830s) is used to undermine the idealization of self-government and progress. Chapter three takes romance as its core topic, while dealing with Nathaniel Hawthorne's, then George 
Lippard's, literary pieces. Mesmerism is then analyzed in relation with the notion of domesticity. Chapter four concentrates on Harriett Beecher Stowe's use of romance, and how her second anti-slavery novel (Dred: A Tale of the Great Dismal Swamp) portrays religious enthusiasm as some "nervous affectation" that can, however, be used by antiabolitionists who want to rail against Northern abolitionists. Chapter five opposes spiritualism and neurology at the end of the $19^{\text {th }}$ century. Through electricity, spiritualism is said to make people communicate with the dead, while neurology adopts a much more rational position.

4 For each of these chapters, the author makes sure that the nervous system is seen at the crossroads of different considerations. Thus Robert Montgomery Bird's comic novel tackles the potentially gothic theme of metempsychosis but it turns it into a farcical story which makes it possible to see hypochondria as some disorder of the internal sympathies of the body. As will be the case throughout the study, Murison then parallels the physiological with the social and the historical (disordered sympathies being, for instance, seen as the inability to control both intrasubjective and intersubjective relations).

Throughout her book, Murison takes also great care to relate these nervous problems to one key issue of antebellum America: slavery and abolitionism. Echoing an $18^{\text {th }}$ century scientific definition according to which sympathy is the way the nervous system keeps organs working together, Murison then goes one step further and associates the notion of sympathy with subjectivity and the culture of sentiment. Physiological sympathy is shown as akin to the idea of the "open body," the human body being vulnerable. Thus, hypochondria, which is described as some pathological flight of fancy, is responsible for the inappropriate sympathetic identification which likens man to a thing, thereby evoking the situation of slaves as mere property. As can be seen, nervous problems are thus always considered in relation to antebellum America, and that is how the issue of slavery and abolitionism comes to the fore.

When it comes to Poe's political satires, Murison stresses the fact that Poe did not aim to please in his grotesque satires. And by using the physiological "reflex arc," the author shows how a reflexive body can undermine self-government and the racial hierarchy on which they rest. Indeed, the lack of control entailed by these unconscious nervous movements (epitomized by Galvani's electrical experiments on decapitated frogs) leads Poe to challenge the relevance of the teleological descriptions of democracy in his days. It then clearly appears that the focus on phrenology and its research on the human brain and the spinal cord becomes a means for Poe to question the triumph of Jacksonian democratic values.

7 Clairvoyance and mesmerism are other key physiological notions alluded to in the third chapter (a chapter devoted to romance with Nathaniel Hawthorne's The Blithedale Romance and George Lippard's The Memoirs of a Preacher). From the 1830s onwards, mesmeric trances and magnetic healing spread across the USA. The notion of the "electrical body" did not wait for Walt Whitman's Leaves of Grass and his poem "I Sing the Body Electric," and the human brain was often compared to some galvanic battery. For those believing in mesmerism, these romances dealing with trances and magnetic healing were supposed to put an end to the duality of spirit and matter. More concretely, the romances are then a way for the American society to consider the role of women as spiritualized "angels of the house" or as concrete corporeal women. By collapsing the boundaries of privacy, mesmerism was seen as potentially paving the 
way for some utopian projects where the domestic space could be transformed and become boundless. Justine S. Murison then reminds us of all the utopian ideals that were aired in those days, whether in France (with Charles Fourier's theories) or on the American land (with Brook Farm for example). Mesmerism and transcendentalism went hand in hand, as the destruction of privacy and private properties was then advocated.

Hawthorne's skeptical view, however, eventually entailed that these romances dealt with failed utopian projects that made it difficult to envisage the blossoming of middleclass domesticity (as possession and bondage seemed to prevail over emancipation). Likewise George Lippard saw the limits and the dangers of mesmerism, and in his novels, he deflated the tensions caused by these excessive trances through conservative stances like that of endorsing marriage.

Though influenced by the ideas of the previous artists and scientists, Harriet Beecher Stowe's novel (Dred. A Tale of the Great Dismal Swamp) manages to escape skepticism and the feeling of impending doom so as to linger on the enthusiasm that can be found in revivalisms. Once again, Justine S. Murison harks back to sciences so as to connect the nervous system with revivalist enthusiasm, the latter being then seen as dangerous for the brain by physicians like Amariah Brigham. Beecher Stowe does not question the connection, yet her diagnosis differs as she does not see anything pathological about the nervousness triggered by revivalism. In Dred more than in Uncle Tom's Cabin, she manages to combine abolitionism, enthusiasm and nervous physiology. Not only is Beecher Stowe's use of enthusiasm poles apart from Hawthorne's skepticism, but she also clashes with sentimental novels that associate religion with an orderly domestic world. By connecting political and religious issues with scientific considerations on nervous physiology, she departs from sentimentalism to reach the realm of realism tinged with romance. But the fervor that can be felt in her novel is thwarted by skepticism in the end, as she, much like Hawthorne, does not lead her characters toward some utopian world. With Beecher Stowe, nervous physiology creates social dynamism... to some extent only.

In chapter five, Justine S. Murison gives a closer look at nervous physiology in the late nineteenth century. The highly traumatic nature of the American civil war assuredly played a major part in the development of spiritualism in the USA. Spiritualists stressed the role of senses and of the nerves so as to receive information from the afterlife. Electricity and telegraphy were seen as major elements for spirits to communicate with the living. In their fictional writings as well as in the nonfictional ones, spiritualists believed that empiricism was to prove their claims. Murison then concentrates on the works of Epes Sargent whose civil war novel, Peculiar. A Tale of the Great Transition, blended realism with visions of heaven, spirit manifestations and considerations on the nervous system.

11 At the other end of the spectrum, neurologists like George Miller Beard tried their best to give some scientific credibility to their conception of the nervous system. Using deduction rather than empiricism, Beard developed his theory of the nervous body as a closed circuit, and he defined neurasthenia as a pathological lack of nerve force. Trying to establish "the expertise of medical neuroscience" (162), Bird opposed the spiritualist attempts at mixing politics, spirits, and the nervous system. And, to give more weight to his neurological studies, he advocated analyzing the patients' ailments by spending time with them and listening to their comments. Freud's talking cure was then not far 
ahead. Murison concludes her last chapter by commenting on William James's specific stance. Thus, the philosopher was neither an adept of the spiritualists' theories (whose empirical methodology he distrusted), nor a follower of the neurologists' too narrowly scientific approach. This opinion was also shared by Elizabeth Stuart Phelps who had a more inclusive view of things, as she was more prone to gather science, physiology, faith and spiritism.

In the short epilogue, Justine S. Murison lays emphasis on William James's peculiar standpoint, the philosopher managing to fuse scientific questions with spiritual ones through the means of nervous physiology. Then in very few pages, the author shows how Sigmund Freud rejected all the research that had been performed before (whether it be Charcot's study on hysteria, or James's theory on emotions and corporeality). With Freud, psychoanalysis was to ignore all the $19^{\text {th }}$ century scientific research on somaticism that represents the core of The Politics of Anxiety in Nineteenth-Century American Literature. Murison then concludes on James's interest in the "susceptibility of the nervous self" which can be found in fiction (177). For Murison, susceptibility will enable "cultures and bodies [to] intermingle" (177), as it will also create the necessary distance for an accurate reader response.

By focusing on somatic nervousness throughout the whole book, Murison therefore gives us a rare view of $19^{\text {th }}$ century American literature. The examples she chooses throughout the five chapters are judicious and shed light on some authors whose fame has not always reached the $20^{\text {th }}$ century, not to mention this day and age. Her style is clear and the examples telling. It is moreover quite an achievement to gather literary analysis, historical data, and physiological considerations in such a tight and convincing manner.

It is however to be deplored that the epilogue is so short and concise. Indeed, in less than four pages, Murison deals not only with the theories of James and Freud, but she also mentions the thoughts of Ricœur, Sedgwick, Felski, Jameson, Greenblatt, or Wald and Castiglia, to name but a few. The list is long and one would have appreciated some more pages to enjoy even more that dark corner of $19^{\text {th }}$ century American literature.

\section{AUTHORS}

\section{CHRISTOPHE CHAMBOST}

Université Bordeaux - Montaigne 